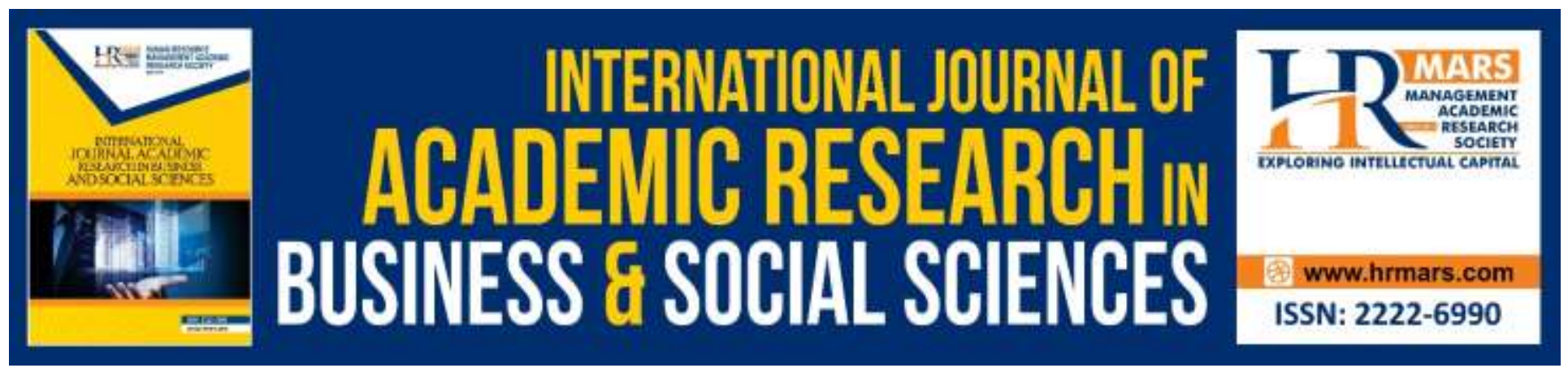

\title{
Influence of Board Composition Practices on Corporate Governance Performance in Public Institutions in Rwanda.
}

\author{
Usengumuremyi Jean Marie Vianney, Mike A. Iravo, Gregory Namusonge
}

To Link this Article: http://dx.doi.org/10.6007/IJARBSS/v10-i3/7057

DOI:10.6007/IJARBSS/v10-i3/7057

Received: 01 February 2020, Revised: 21 February 2020, Accepted: 11 March 2020

Published Online: 28 March 2020

In-Text Citation: (Vianney et al., 2020)

To Cite this Article: Vianney, U. J. M., Iravo, M. A., \& Namusonge, G. (2020). Influence of Board Composition Practices on Corporate Governance Performance in Public Institutions in Rwanda. International Journal of Academic Research in Business and Social Sciences, 10(3), 386-395.

Copyright: (C) 2020 The Author(s)

Published by Human Resource Management Academic Research Society (www.hrmars.com)

This article is published under the Creative Commons Attribution (CC BY 4.0) license. Anyone may reproduce, distribute, translate and create derivative works of this article (for both commercial and non-commercial purposes), subject to full attribution to the original publication and authors. The full terms of this license may be seen

at: http://creativecommons.org/licences/by/4.0/legalcode

Vol. 10, No. 3, 2020, Pg. $386-395$

http://hrmars.com/index.php/pages/detail/IJARBSS

JOURNAL HOMEPAGE

Full Terms \& Conditions of access and use can be found at http://hrmars.com/index.php/pages/detail/publication-ethics 


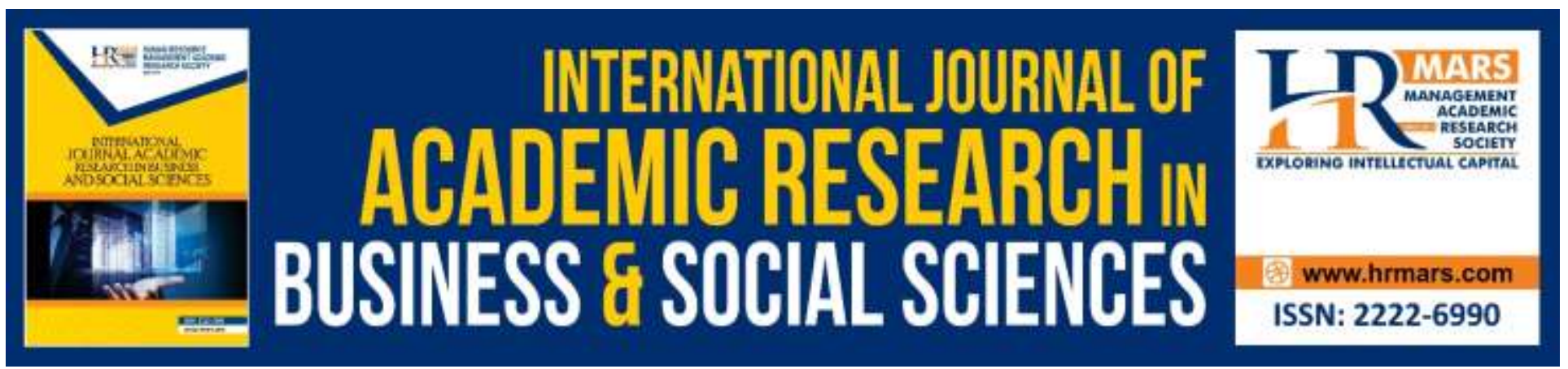

\title{
Influence of Board Composition Practices on Corporate Governance Performance in Public Institutions in Rwanda.
}

\author{
Usengumuremyi Jean Marie Vianney \\ Jomo Kenyatta University of Agriculture and Technology, Kigali, Rwanda. \\ Prof. Mike A. Iravo, Prof. Gregory Namusonge \\ Jomo Kenyatta University of Agriculture and Technology, Juja Kenya.
}

\begin{abstract}
Board composition practices are essential for improvement of performance in public entities. The purpose of this study was to examine the influence of Board composition practices on Governance Performance public institutions in Rwanda. Board leadership practices has dominated the corporate governance performance agenda in developed market economies for more than a decade and the African continent is gradually adopting it in shaping the policy agenda of the leadership and governance of her organizations. The study adopted a descriptive and explorative design since its main purpose was to explain the of board leadership practices on governance performance in public institutions in Rwanda. The target population for the study was 378 managers from 10 public institutions in Rwanda. Stratified random sampling technique was used to get a sample of 195 respondents who were selected from the top management and middle managers staff. Data for the study was collected by use of questionnaires, interviews and observation using descriptive and inferential statistics to establish the relationship between the dependent and independent variables. It was expected that the results of the study would assist the top management of the institutions, as well as other stakeholders, to understand the effect of board leadership practices on governance performance in public institutions in Rwanda. Data collected was analyzed through SPSS version 21. Data analysis involved statistical computations for averages, percentages, and correlation and regression analysis. Ordinary least squares (OLS) regression method of analysis was adopted to determine the inferential statistics. Board composition practices had a positive relationship with corporate governance performance public institutions in Rwanda ( $r=0.765, p<0.001)$ at 0.05 level of significance. The analysis showed that Board composition practices had the strongest relationship with the corporate governance performance in public institutions in Rwanda since it had the highest positive coefficient of $(r=0.765)$. The findings confirm that there is a statistically significant influence of Board composition practices and corporate governance performance in public institutions in
\end{abstract}


INTERNATIONAL JOURNAL OF ACADEMIC RESEARCH IN BUSINESS AND SOCIAL SCIENCES Vol. 10, No. 3, March, 2020, E-ISSN: 2222-6990 @ 2020 HRMARS

Rwanda. The study concludes that board composition practices are effective in determining corporate governance performance in public institutions in Rwanda. The study examined the effect of board leadership practices on corporate governance performance in public institutions in Rwanda, the dependent variable corporate governance performance and the independent variable Board composition practices, there are other mediating or intervening factors that can affect corporate governance performance that could be researched further for example type of leadership. Therefore, future studies can introduce other moderating or an intervening variable in their models.

Keywords: Corporate Governance Performance, Board Composition Practices, Public institutions in Rwanda.

\section{Introduction}

Globally, Board composition has been a subject receiving increased attention during the last three decades. Public institutions especially in the last decades have realized the importance of composing effective boards of directors in order to maximize organizational performance (Beekes, Pope \& Young, 2012). Boards have long had the legal authority and shareholder encouragement to proactively oversee executive decision making. Boards with relevant knowledge, skills, and abilities have the potential for proffering unique tactical and strategic advantages to corporations (Finkelstein \& Hambrick, 2014). They can contribute to a firm's success through three primary roles: the resource role wherein they enhance access to critical external resources, the service role in which they provide important advice to executive management, and the control role in which they provide governance oversight and determine incentives for executive performance (Chatterjee \& Harrison, 2014). To do this, boards require financial resources which are affected by the firm's capital structure.

In the process of securing board members entails determining the skills and competencies needed on the board and then developing procedures that facilitates the identification and selection of appropriate members (Daily \& Dalton, 2014; Lee \& Phan, 2010; Metz, 2008). For instance, Herman and Renz (2000) found that written expectations (of giving and soliciting) for board members was present in the most effective organizations. Similarly, human resource management and volunteer management recognize the importance of systematic job design and specification (Brannick \& Levine, 2012; Heidrich, 2010). As stated in every human resource management textbook, clear specification of position requirements is the backbone of effective recruitment (Pynes, 2014). The prevalence of these practices in nonprofit governance is not clear, but the best practice recommendation is fairly widely recognized (Watson, 2014).

The board should therefore be structured and composed of in such a way that it will act to monitor itself. Rashid (2011) states that "corporate governance literature debated within two extreme streams of board practices examining whether the board composition in the form of representation of outside independent directors and structural dependence of the board influence the firm financial performance. The available literature on the relationship between the board composition and firm financial performance reflects mixed results. The idea of endogenous relationship between board composition and corporate performance was advanced by Hermalin \& Weisbach (2013), that is, board composition and corporate performance jointly influence each other rather the board composition influencing corporate performance or corporate performance influencing board composition. Davidson \& Rowe (2014) note that board composition and financial performance influence each other but the effect is not immediate. 
Corporate governance performance deals with the way in which public institutions assure themselves of achieving the milestones towards the country development (Shleifer \& Vishny, 1997). From global perspective, corporate governance is still a hot topic among shareholders, regulators and society at large and received increased attention in the past decades (Smolo \& Smajic, 2011). This is due to collapsed of big corporation such as Lehman Bros., J.P. Morgan, Morgan Stanley and others, fraudulent activities, several major corporate scandals and long-lasting economic depression that raised the questions on the suitability of existing governance practices of public institutions (Mazudmer, 2013). In Rwandan context, corporate governance has also gained prominence (Ekadah \& Mboya, 2012). This has been caused partly by corporate failure or poor performance of public and private companies (Barako et al., 2006). There is need to carry a research to examine the influence of Board composition practices on corporate governance performance in public institutions in Rwanda.

\section{Objectives of the Study}

This study was guided by the following research objective:

1. To examine the influence of Board composition practices on corporate governance performance in public institutions in Rwanda.

\section{Statement of the Problem}

Despite the impressive corporate governance performance of the public institutions in Rwanda, most public organizations are still dogged with challenges of poor board composition that has resulted to frequent changes of the ministers, directors and in general the board of directors. Board of directors are ultimately accountable for policies, practices, and procedures that will determine whether the organization prosper or collapse. Regular and timely evaluation of the board performance is critical to ensure that they are not only serving their interests but the shareholders interest at large. Due to greater need for accountability by shareholders, government entities and general public, the management boards have to evaluate their performance so that it aligns with the organization's performance (Rahman \& Castelli, 2013).

Previous study has several literature gaps that are filled by this study. Most of the study has concentrated on the relationship between board composition and financial performance. There is therefore clear evidence that the relationship between board composition as a determinant of corporate governance performance have not been studied simultaneously. Therefore, this study sought to fill this gap by critically evaluating effect of board composition practices on corporate governance performance in public institutions in Rwanda by answering the research question: Does board composition practices have any influence on corporate governance performance in public institutions in Rwanda?

\section{Justification of Study}

The study is of value to Policy makers in public institutions in Rwanda. Policy can use the findings of the study to examine critical areas surrounding Corporate Governance and to formulate necessary policies as guiding frameworks for Corporate Governance in public institutions in Rwanda. The recommendations of the study will assist policy makers as a reference for future policies on effectiveness of corporate governance so as to increase public trust in public institutions in Rwanda. 
INTERNATIONAL JOURNAL OF ACADEMIC RESEARCH IN BUSINESS AND SOCIAL SCIENCES

Vol. 10, No. 3, March, 2020, E-ISSN: 2222-6990 (C) 2020 HRMARS

\section{Theoretical Perspective}

This paper discusses the agency Theory upon which the study is anchored

\section{Agency Theory}

In contemporary corporations the shareholders (principals) are dispersed widely and are therefore not commonly included in the day to day processes and administration of their respective firms, rather, they hire managers (agent) to govern the companies on their behalf. The officials are engaged to manage the daily tasks of the organization. The separation of ownership and controlling rights may result in disputes of interest between agent and principal (Habbash, 2010). Being an annex of the agency view, the theory anticipates agents to manage the welfare of the principals. However, this tapered attention on stakeholders has experienced a disparity and managers are now expected to consider the welfares of several other investor groups (Freeman et. al 2004).

According to Habbash (2010) has received greater attention from academic and practitioners, contends that as firms expand in size the principals (shareholders) lose effective control thereby allotting professional managers (agents) to manage the business. In doing so, the agents over time steadily gain effective control over the business (Mizruchi, 2013).

In contemporary corporations the shareholders (principals) are dispersed widely and are therefore not normally involved in the daily operations and management of their respective firms, rather, they hire managers (agents) to manage the corporation on behalf of them. The agents are engaged to manage the day to day operations of the corporation. The separation of ownership and controlling rights may result in disputes of interest between agent and principal (Habbash, 2010).

The fundamental principle of agency theory is that agents (managers) act out of self-interest and are self-centered, thereby, give less attention to shareholder interests which ends up causing a negative impact on overall firm value. As long as the principal and agent utilities coincide, there is no agency problem. However, once their interests diverge; the agent sought to maximize his utility at the expense of the principal (Eisenhardt, 2009).

In addressing the key agency issues, Coleman, 2007, presented the following ways of addressing the opportunistic tendencies of agents. Independent directors; Agency theory presume board of directors to incorporate a large percentage of independent directors for effective control. This is meant to reduce conflict of interest between agents and principals and thereby ensures a board's independence in monitoring and passing fair and unbiased judgment on management. Addressing the agency theory board composition in terms of size, gender and age is very crucial that requires an agency to ensure board corporate performance. 
INTERNATIONAL JOURNAL OF ACADEMIC RESEARCH IN BUSINESS AND SOCIAL SCIENCES

Vol. 10, No. 3, March, 2020, E-ISSN: 2222-6990 @ 2020 HRMARS

\section{Conceptual Framework Independent variables}

\section{Dependent variable}

Board Composition practices

- Board Size

- Board Gender

- Board Age

\section{Corporate Governance Performance}

- Quality Service

- Accountability

- Stakeholder Involvement

- Customer Satisfaction

Figure 2.1 Conceptual framework

\section{Research Methodology}

The study used a cross-sectional survey research design. Cross-sectional surveys involve data collection from a population, or a representative subset, at one specific point in time and have an advantage over other research designs that only seek individuals with a specific characteristic, with a sample, often a tiny minority, of the rest of the population (Kothari, 2011).

A sample size of 195 respondents was determined from a total population of 378 individuals using the formula by Yamane (1967).

Where $\mathrm{n}=$ the desired sample size

$$
n=\frac{N}{1+N(e)^{2}}
$$

$\mathrm{e}=$ probability of error (i.e. the desired precision e.g. 0.05 for $95 \%$ confidence level)

$\mathrm{N}=$ the estimate of the population size.

$$
n=\frac{378}{1+378(0.05)^{2}}=195
$$

Primary data was collected using structured questionnaires which had both close ended and openended questionnaires. Structured questionnaires refer to questions which are accompanied by a list of all possible alternatives from which the respondents select the answer that best describe their situation (Mugenda \& Mugenda, 2009). Structured questions are easier to analyze since they are in the immediate usable form (Orodho, 2008). The questionnaires were self-administered. The researcher informed the respondents that the instruments being administered was for research purpose only and the response from the respondents were kept confidential. The researcher obtained an introductory letter from the University in order to collect data from the field and then delivered the questionnaires to the respondents with the help of a research assistant using the drop and pick later method.

\section{Analysis for Board Composition Practices}

Regression analysis was performed in order to determine whether the independent variable, Board composition practices, could be reliable for explaining the change in the dependent variable, corporate governance performance in public institutions in Rwanda. The coefficients obtained indicate that the correlation coefficient $(R)$ between the independent variable and the corporate governance performance in public institutions in Rwanda was 0.994 which is a positive correlation relationship. Table 1 shows a coefficient of determination $\left(R^{2}\right)$ of 0.570 , which means that this 
INTERNATIONAL JOURNAL OF ACADEMIC RESEARCH IN BUSINESS AND SOCIAL SCIENCES Vol. 10, No. 3, March, 2020, E-ISSN: 2222-6990 C 2020 HRMARS

variable alone can explain up to $57.0 \%$ of the variations in the dependent variable, corporate governance performance in public institutions in Rwanda. This implies that there exists a positive significant relationship between board composition practices and corporate governance performance in public institutions in Rwanda.

Table 1: Model summary showing Board composition practices

\begin{tabular}{llccc}
\hline Model & $\mathbf{R}$ & R Square & Adjusted R Square & Std. Error of the Estimate \\
\hline $\mathbf{1}$ & $.755^{\mathrm{a}}$ & .570 & .567 & .65724
\end{tabular}

a. Predictors: (Constant), Board composition practices

The results of an Analysis of Variance (ANOVA) test performed on the variable Board composition practices are summarized in Table 2. The findings further confirm that the regression model of variable board composition practices on corporate governance performance is significant and supported by $F=201.134, p<0.01$ ) since $p$-values was 0.00 which is less than 0.05 .

Table 2: ANOVA for Board composition practices

\begin{tabular}{llccccc}
\hline Model & & Sum of Squares & Df & Mean Square & F & Sig. \\
\hline \multirow{2}{*}{1} & Regression & 42.431 & 1 & 42.431 & 201.134 & $.000^{\text {a }}$ \\
& Residual & 33.811 & 82 & .617 & & \\
& Total & 76.242 & 83 & & & \\
\hline
\end{tabular}

b. Dependent Variable: Corporate governance performance

c. Predictors: (Constant), Board composition practices

The coefficients of board composition practices are presented in Table 3 which indicate that the model has a significant $p$-value $=.000$. The study at $95 \%$ confidence interval solved the first research question by indicating that the variable board composition practices is statistically significant in the corporate governance performance public institutions in Rwanda.

Table 3: Coefficients of board composition practices.

\begin{tabular}{|c|c|c|c|c|c|c|c|}
\hline \multirow[t]{2}{*}{ Model } & & & \multicolumn{2}{|c|}{$\begin{array}{l}\text { Unstandardized } \\
\text { Coefficients }\end{array}$} & \multirow{2}{*}{$\begin{array}{l}\text { Standardized } \\
\text { Coefficients } \\
\text { Beta }\end{array}$} & \multirow[t]{2}{*}{$\mathbf{T}$} & \multirow[t]{2}{*}{ Sig. } \\
\hline & & & B & Std. Error & & & \\
\hline \multirow[t]{2}{*}{1} & (Constant) & & .773 & .231 & & 5.973 & .000 \\
\hline & $\begin{array}{l}\text { Board } \\
\text { practices(X1) }\end{array}$ & composition & .539 & .062 & .444 & 8.815 & .000 \\
\hline
\end{tabular}

a. Dependent variable: corporate governance performance 
INTERNATIONAL JOURNAL OF ACADEMIC RESEARCH IN BUSINESS AND SOCIAL SCIENCES

Vol. 10, No. 3, March, 2020, E-ISSN: 2222-6990 @ 2020 HRMARS

Using the summary of Coefficients presented in Table 3, a linear regression model of the form, $Y=\alpha$ $+\beta X i$ can be fitted as follows:

$Y=0.773+0.539 \times 1$ Equation 1

This implied that a unit change in board composition practices would increase corporate governance performance by the rate of 0.539 .

\section{Hypothesis Testing for Board Composition Practices}

$\mathrm{HO}_{1}$ : There is no significant influence between Board composition practices on corporate governance performance public institutions in Rwanda.

The hypothesis was tested by using multiple linear regression and determined using $p$-value. The acceptance/rejection criteria were that, if the $\mathrm{p}$ value is less than 0.05 , was to reject the $\mathrm{H}_{\mathrm{A} 1}$ but if it was more than 0.05 , the $\mathrm{H}_{\mathrm{A} 1}$ is not rejected. Therefore, the alternative hypothesis is that there is significant influence between Board composition practices on corporate governance performance public institutions in Rwanda. Results in Table 2 shows that the $p$-value was 0.021 . This was supported by a calculated t-statistic of 2.112 that is larger than the critical t-statistic of 1.96. The alternative hypothesis was therefore not rejected. The study therefore adopted the alternative hypothesis that that there is significant influence between Board composition practices on corporate governance performance public institutions in Rwanda.

\section{Conclusion on Board Composition Practices and Corporate Governance Performance}

The findings confirm that there is a statistically significant influence of Board composition practices and corporate governance performance in public institutions in Rwanda. A positive increase in Board composition practices leads to an increase in corporate governance performance in public institutions in Rwanda. It can be concluded from this study that Board composition practices were statistically significant in explaining corporate governance performance in public institutions in Rwanda. The study concludes that are effective in determining corporate governance performance in public institutions in Rwanda.

\section{Areas for Further Research}

The study examined the effect of board composition practices on corporate governance performance in public institutions in Rwanda, the dependent variable corporate governance performance and the independent variable being Board composition practices. There are other mediating or intervening factors that can affect corporate governance performance that could be researched further for example type of leadership. Therefore, future studies can introduce other moderating or an intervening variable in their models.

Secondly, this study used cross-sectional research design which means that the constructs were measured from a static perspective. Future studies should use a longitudinal study which would provide more insight. Finally, the present study used data drawn from the same respondents at a multiple country using the same collection method. Self-rating of each public institutions in Rwanda can provide more insight on how board leadership practices is unique and its influence in corporate governance performance in public institutions in Rwanda. 
INTERNATIONAL JOURNAL OF ACADEMIC RESEARCH IN BUSINESS AND SOCIAL SCIENCES

Vol. 10, No. 3, March, 2020, E-ISSN: 2222-6990 (C) 2020 HRMARS

\section{References}

Barako, D. G., Hancock, P., \& Izan, H. Y. (2006). Factors Influencing Voluntary Corporate Disclosure by Kenyan Companies. Corporate Governance: An International Review, 14(2), 107125.

Beekes, W., Pope, P., and Young, S. (2012). "The Link between Earnings Timeliness, Earnings Conservatism, and Board Composition: Evidence from the UK," Board composition, 12 (1), 4759.

Brannick, M. T., \& Levine, E. L. (2012). Job analysis: methods, research, and applications for human resource management in the new millennium. Thousand Oaks, CA: Sage Publications.

Chatterjee, S., and Harrison, J. (2014). Handbook of Strategic Management, Blackwell Publishing, Malden, MA: 543-561

Coleman, A. (2007). The impact of capital structure on the performance of microfinance institutions. The Journal of Risk Finance, 8(1), 56-71.

Daily, C. M. and Dalton, D. R. (2014), The Relationship between Governance Structure and Corporate Performance in Entrepreneurial Firms, Journal of Business Venturing, 7 (5): 375-386.

Davidson III, W. N. and Rowe, W. (2014), Intertemporal Endogeneity in Board Composition and Financial Performance, Corporate Ownership and Control, 1 (4): 49-60.

Eisenhardt, K. M. (2009). Agency theory: An assessment and review. Academy of management review, 14(1), 57-74.

Ekadah, J. W., \& Mboya, J. (2012). Effect of Board Gender Diversity on the Performance of Commercial Banks in Kenya. European Scientific Journal, 8(7)

Finkelstein, S. and Hambrick, D., (2014). Strategic Leadership: Top Executives and them Effects on Organizations, West Publishing Company, Minneapolis/St. Paul, MN: 1-37

Freeman, R. E., Wicks, A. C., \& Parmar, B. (2004). Stakeholder theory and "the corporate objective revisited". Organization science, 15(3), 364-369.

Habbash, M. (2010). Corporate environmental disclosure, corporate governance and earnings management. Accounting and Finance Division, Stirling Management School, Stirling University, Stirling, UK

Heidrich, K. W. (2010). Working with Volunteers. Champaign, IL: Sagamore.

Herman, R. D., \& Renz, D. O. (2000). Board practices of especially effective and less effective local nonprofit organizations. American Review of Public Administration

Hermalin, B. E., and Weisbach, M. S. (2013), Board of Directors as an Endogenously Determined Institution: A Survey of the Economic Literature, Economic Policy Review, 9 (1): 7-26.

Kothari, C. R. (2011). Research methodology: methods and techniques. New Delhi: New Age International.

Lee S. H., \& Phan, P. H. (2010). Competencies of directors in global firms: Requirements for recruitment and evaluation. Corporate Governance, 8,

Mazudmer, M. M. M. (2013). Corporate governance practices in Japan: Post-crisis reforms, successive changes and future trends. International Journal of Business, Management And Social Sciences, 4(1), 1-11. 
INTERNATIONAL JOURNAL OF ACADEMIC RESEARCH IN BUSINESS AND SOCIAL SCIENCES

Vol. 10, No. 3, March, 2020, E-ISSN: 2222-6990 (C) 2020 HRMARS

Metz, E. J. (2008). Designing succession systems for new competitive realities. Human Resource Planning,

Mizruchi, M. S. (2013). Who controls whom? An examination of the relation between management and boards of directors in large American corporations. Academy of management Review, 8(3), 426-435.

Mugenda, M., \& Mugenda, G. A. (2009). Research methods, qualitative and qualitative approaches, Nairobi: Acts Press.

Orodho, J. A. (2008). Techniques of writing research proposals and reports in education and social sciences. Nairobi: Masola Publishers.

Pynes, J. E. (2014). Human resources management for public and nonprofit organizations, 2nd Ed. San Francisco:

Rahman, W. A. \& Castelli, P. (2013). The Impact of Empathy on Leadership Effectiveness among Business Leaders in the United States and Malaysia, International Journal of Economics Business and Management Studies, 2(3).

Rashid, A. (2011). Board Composition Board Leadership Structure and Firm Performance: Evidence from Kenya. A Paper for Inclusion in the Accounting and Finance Association Australia and New Zealand Annual Conference Adelaide, July 5-7th.

Shleifer, A., \& Vishny, R. W. (1997). A Survey of Corporate Governance. The Journal of Finance, 52(2), 737-783.

Smolo, E., \& Smajic, M. (2011). Recent fiasco in Qatar: The need for good governance. ISRA Bulletin, 8, April 2011, pp. 3 - 4.

Watson, E. (2014). Public-sector corporate governance: British Columbia's best-practices reforms. Ivey Business Journal Online. 